\title{
A DINÂMICA DO ENLUTAMENTO NA SOCIEDADE ISRAELENSE CONTEMPORÂNEA E SEUS ECOS NA LITERATURA DE DAVID GROSSMAN
}

\section{THE DYNAMICS OF GRIEVING IN CONTEMPORARY ISRAELI SOCIETY AND ITS ECHOES IN DAVID GROSSMAN'S LITERATURE}

Karla Louise de Ameida Petel*

\section{Resumo}

O presente artigo objetiva refletir sobre a dinâmica do enlutamento existente na sociedade israelense contemporânea e sobre em quais momentos/eventos históricos reside a sua origem. Esta pesquisa busca também analisar a flagrante manutenção da dor e do trauma como experiência individual e coletiva em Israel, reforçados pelo próprio Estado através de inúmeras datas e rituais memorialísticos, chegando a atingir proporções nacionais. Consolidado como uma verdadeira construção social, o enlutamento, portanto, passa a fazer parte da dura realidade cotidiana do país e ressoa nas mais diversas manifestações artísticas da sociedade, sobretudo a literatura. Por fim, este trabalho dedica-se ainda a uma leitura analítico-interpretativa de duas obras do autor contemporâneo israelense David Grossman - $A$ mulher foge (2011) e Fora do tempo (2012) - as quais contém ecos muito significativos da temática da morte e do luto característicos da sociedade israelense.

Palavras-chave: dinâmica do enlutamento, sociedade israelense, literatura contemporânea de Israel, David Grossman.

\begin{abstract}
This article aims to reflect about the dynamics of grieving that exhists in contemporary Israeli society and at which historical moments/events it is possible to find its origin. This research also seeks to analyze the blatant maintenance of the pain and of the trauma as individual and collective experience in Israel, reinforced by the State through numerous dates and

\footnotetext{
* Doutoranda em Estudos Judaicos pelo Programa de Pós-Graduação em Estudos Judaicos e Árabes da Universidade de São Paulo e Professora do Departamento de Língua e Literatura Hebraicas da Universidade Federal do Rio de Janeiro.
} 
memorialistic rituals, which end up reaching national proportions. Consolidated as a true social construction, the bereavement thus becomes part of the hard everyday reality of the country and resonates in various artistic expressions of society, especially the literature. Finally, this work also is dedicated to an analytical and interpretative reading of two texts by Israeli contemporary author David Grossman - To the End of the Land (2011) and Falling Out of Time (2012) - which contains very significant echoes of the death and the grieving, typical themes in Israeli society.

Keywords: bereavement dynamics, Israeli society, contemporary literature of Israel, David Grossman. 


\section{Introdução}

Durante seus quase 70 anos de existência, o Estado de Israel experimentou, pelo menos, cinco grandes conflitos militares - Guerra da Independência (1948), Guerra dos Seis Dias (1967), Guerra de Yom Kippur (1973) e duas incursões no Líbano (1982 e 2006). Esses eventos, bem como outras ações de menor porte e repentinos ataques terroristas, criaram condições muito específicas, responsáveis por moldar a identidade israelense e fazer com que a sociedade fosse imersa em uma dinâmica muito particular.

Estima-se que, de uma população que, atualmente, passa um pouco de 8.000.000 de pessoas, aproximadamente 20.000 jovens militares tenham sido mortos durante sua atuação no exército. Isso fez com que, ao longo dos anos, um cenário fosse reconhecido como tipicamente próprio de Israel: o do enlutamento permanente, ou seja, o do luto como um processo, mais do que um estado ou uma fase.

Apesar de o luto familiar estar em um nível muito pessoal e ser uma experiência essencialmente particular, o que se identifica na sociedade contemporânea israelense é que o enlutamento coletivo também se instaura em seu cotidiano, criando uma estreita relação entre um sentimento de caráter íntimo e uma consternação de proporção nacional, reforçada por diversos rituais memorialísticos por todo o país.

Para Riches e Dawson (1996, p. 143-162), com o expressivo número de soldados mortos em conflitos, desenvolveu-se, em Israel, portanto, uma espécie de "cultura do luto", que está fortemente relacionada à ideia de sacrifício e heroísmo por parte desses jovens alistados no exército. Desse modo, o que se pode verificar é que a dinâmica dessa sociedade contribui significativamente para a manutenção da melancolia, não só porque absorve intensamente a dor das famílias que perderam seus filhos e filhas, mas também porque entra em constante rememoração dos eventos traumáticos. Nesse sentido, a tragédia, que, em princípio, deveria concernir a um restrito número de indivíduos, passa a ser uma tristeza amplamente coletiva; e a memória da perda de um filho, que seria algo muito particular, se converte na memória da perda de um soldado que deu a vida pelo seu país.

De acordo com Rubin, Malkinson e Witztun (1999), inúmeras cerimônias pela recordação dos militares tombados nas guerras, monumentos que celebram a coragem e a morte heroica de seus soldados, dias individuais de lembrança no contexto familiar, assim como atos públicos nacionais, estimulam uma intermitente expressão de desconsolo pelas 
perdas. Esses exemplos são manifestações concretas de uma sociedade não só afetada, mas construída sobre a dinâmica da morte e do luto, o que a faz potencialmente diferente das demais sociedades do mundo e alvo de maior atenção e pesquisa.

O fenômeno do enlutamento decorrente da perda dos jovens combatentes como algo tão próprio da sociedade israelense acaba por permear, como não poderia deixar de ser, diversas manifestações sociais e artísticas do país, nas mais variadas instâncias. Essa tendência é, então, incorporada, por exemplo, por instituições de ajuda mútua e organizações de famílias enlutadas, além de ser igualmente absorvida pelas artes plásticas, música, teatro e literatura. $\mathrm{O}$ reflexo natural de que inúmeras expressões se ocupem desse tema revela que, de fato, a sociedade israelense - em especial, sua população judaica - se encontra em uma mesma frequência de luto e tristeza, de maneira que há uma flagrante manutenção de sentimentos e memórias individuais e coletivas concernentes à realidade conflitiva cotidiana do país.

Diante de tão complexas questões, o presente trabalho objetiva refletir sobre essa condição característica da sociedade israelense, através, primeiro, de uma perspectiva sóciohistórica e, em seguida, através de sua produção literária recente. A análise partirá, portanto, de considerações sobre a dinâmica do enlutamento desde sua origem, consolidação e manutenção, seguindo em direção à literatura contemporânea de David Grossman, na qual essa temática ecoa de forma muito representativa. Por ser o próprio autor um pai enlutado, tendo perdido um de seus filhos durante uma incursão militar no sul do Líbano, no ano de 2006, a análise de seus textos como um dos espelhos da sociedade enlutada de Israel se torna ainda mais relevante. Por fim, este estudo propõe uma leitura interpretativa especificamente voltada para as obras A mulher foge (2006) e Fora do tempo (2012), como opção de investigação social, uma vez que à literatura cabe também a representação artística da trajetória histórica e política de uma sociedade.

\section{A sociedade israelense atual e a origem da dinâmica do enlutamento}

Desde antes mesmo da criação do Estado, a sociedade israelense apresenta, entre outras necessidades flagrantes, aquela que, talvez, seja a mais urgente de todas: a de aprender a lidar com perdas. Apesar de tal imperativo se mostrar próprio de sua vida cotidiana desde o período préEstado, o foco sobre a perda de jovens militares em Israel tem evoluído mais gradualmente a partir das últimas quatro décadas. Podem-se destacar diversos eventos que contribuíram para o desenvolvimento do luto no país, mas foi mais precisamente com a Guerra do Yom Kippur, em 
1973, que a questão ganhou vulto. A partir desse momento, o tema também recebeu atenção especial e legitimação no meio acadêmico. De acordo com Levy, Witztum, e Solomon (1996, p. 89-102), a perda de 2.564 jovens adultos nessa guerra e sua disrupção 25 anos após a criação do Estado permitiram que a psicologia geral e o problema da perda em particular figurassem na agenda social do país.

A Guerra da Independência, no ano de 1948, já havia contribuído, em certa medida, para a dinâmica do enlutamento que o Estado de Israel desenvolveria mais tarde, pois deixou um grande número de famílias enlutadas, cujos pais eram da geração que fundara o Estado de Israel - a geração representante do protótipo do "judeu novo" no recém-criado país, que se diferenciava do "judeu frágil" da diáspora. Baseando a identidade coletiva na nacionalidade judaica, a geração dos pioneiros exigiu soluções sociais também coletivas para as "necessidades" criadas pelo luto decorrente do conflito. Ela tinha que expressar os significados que a sociedade havia concedido às mortes de seus filhos em guerra, relacionando-as à ideia de sacrifício e salientando as conotações heroicas inerentes a elas.

Contudo, apesar do componente de valorização do sacrifício, que sempre fez parte da identidade israelense, é preciso sublinhar que o período de 1948 até 1967 foi marcado pela narrativa nacional dominante, na qual as características mais proeminentes do luto coletivo foram contidas: a dor foi reprimida, e o pesar individual era uma emoção silenciosa expressa por trás das portas fechadas das casas das famílias enlutadas. A idealização dos soldados caídos, a vida sacrificial, a negação da dor da perda e a negação da agonia do quase extermínio dos judeus durante a Segunda Guerra Mundial caracterizaram essa fase. Tal contenção emocional coletiva, assim, relacionava-se intimamente ao recente passado de impotência do povo judeu. Os anos que se seguiram ao estabelecimento do Estado foram um misto de consternação pela tragédia dos judeus da Europa e de euforia pelo lar nacional que se criava.

Foi com a Guerra de Independência que se iniciou, por exemplo, a construção social da expressão "família enlutada" e que se constituiu, efetivamente, um grupo da sociedade cujas mortes de seus filhos estivessem fortemente entrelaçadas à garantia de existência e segurança do Estado. A expressão também simboliza o destino comum de todas as famílias israelenses cujos filhos vieram ou viriam a tombar nos conflitos, além do lugar de honra que a sociedade atribui a elas em sua história nacional. Em muitos aspectos, as famílias dos enlutados representam uma espécie de "memorial vivo" (VOLKAN, 1981).

Diretamente relacionada a esse aspecto, está justamente a entidade do Exército Israelense e o papel que ela exerce atualmente na sociedade. As forças militares em Israel têm 
sido forte influenciador social ao longo dos anos, tendo múltiplos significados para diversos grupos. Além de exercer o papel principal de protetor da população e do Estado, o Exército tem cumprido função integradora e é visto como um símbolo de orgulho nacional. $\mathrm{Na}$ sociedade judaica israelense, o alistamento militar tem servido como ponto de encontro para ashkenazim e sefaradim, por exemplo, nativos e imigrantes, além de reunir pessoas de várias formações educacionais e condições socioeconômicas diferentes.

Entretanto, cabe ressaltar que, atualmente, conforme amadurece a sociedade israelense e se enfraquecem as visões demasiadamente tradicionais, coletivistas e comunitárias, o status social idealizado do Exército e do seu papel está passando por transformações. Contudo, a atitude dos cidadãos para com os pais que perderam seus filhos durante o serviço militar e mesmo para com aqueles que são reservistas ainda reflete um grau de consenso característico de apreciação de uma sociedade e da importância que ela dá ao sacrifício individual para o bem comum (RUBIN, MALKINSON \& WITZTUN, 1999).

\section{Enlutamento individual e enlutamento coletivo em Israel}

Como já abordado anteriormente, o contexto no qual a sociedade israelense está inserida nos dias atuais vem sendo construído mesmo antes da fundação do Estado, mas também vem se delineando a partir de duras experiências no relacionamento com os países árabes vizinhos. Entretanto, o desafio não diz respeito somente ao adversário exterior, mas também concerne ao âmbito interno, com o expressivo número de árabes que, hoje, integram a própria sociedade de Israel, mas cuja integração a ela sofre diversas limitações. Participando como protagonista em diferentes guerras, administrando conflitos internos, além de iminentes ataques terroristas, Israel se sente obrigado a permanecer em constante vigilância. Dessa forma, seu cotidiano de prontidão para o combate ajudou a forjar uma sociedade que está sempre na expectativa de um novo episódio de guerra e, consequentemente, contribuiu para que todas as famílias do país se preparassem para o dia em que receberiam do Exército de Israel o envelope marrom com a convocatória dos seus filhos para o alistamento.

Desse modo, a integração dos jovens ao exército também traz consigo não só o receio da perda por parte da família, como, em muitos casos, a confirmação dela. O luto passa a ser um processo comum pelo qual muitos pais israelenses têm de passar, o que gera certa agitação e comoção social. 
Para Sigmund Freud (1915, p. 245-263), o luto é uma reação à perda de, na maioria das vezes, um ente querido, mas também, às vezes, de algo que assuma as mesmas proporções. Para o psicanalista, o luto é, ainda, um fenômeno mental, natural e constante durante o desenvolvimento da vida humana. No luto, nada existe de inconsciente em relação à perda, ou seja, a pessoa enlutada sabe exatamente o que perdeu, demonstrando incapacidade de substituir o indivíduo/objeto alvo de seu amor. Além disso, o luto é um processo que pode ser superado após algum tempo e, por mais que tenha um caráter patológico, não é considerado doença.

De acordo com Malkinson e Bar-Tur (1999),

O luto que segue uma perda através da morte é considerado como uma reação normal e universal. $\mathrm{O}$ curso do luto, seus componentes e suas fases têm sido identificados. Eles incluem reações biopsicológicas, conhecidas por sua alta intensidade imediatamente depois da perda, com expectativa por sua diminuição através do tempo. (MALKINSON; BAR-TUR, 1999, p. 415 [tradução nossa]).

O processo de enlutamento pode ser lento e doloroso; contudo, a superação através da passagem do tempo é consenso entre a maioria dos autores da área e no que se refere à maior parte dos contextos sociais. É justamente nisso que a sociedade israelense difere significativamente das outras. A questão é complexa não só porque o enlutamento é um fenômeno relativamente comum e que faz parte da vida cotidiana dos cidadãos de Israel, mas por ele ser, inclusive, encorajado. Ele não se configura em absoluto como momentâneo, mas se consolida como uma espécie de dinâmica, cuja manutenção é flagrante mesmo muito tempo depois de passado o evento-marco da morte.

Em hebraico, a expressão para designar o fenômeno específico dos "pais enlutados" por perderem seus filhos em guerras é horim shkhulim. Em Israel, essa espécie de orfandade às avessas é bem característica em sua realidade, que, estimulada por atividades oficiais do governo, desenvolveu suas próprias representações coletivas como parte do significado agregado à morte dos filhos em combate. Ainda segundo Malkinson e Bar-Tur (1999), “a expressão 'família enlutada' incorpora determinada atitude e é usada para se referir diretamente aos afetados pela perda do ente amado especificamente em ação militar" (MALKINSON; BAR-TUR, 1999, p. 413-414 [tradução nossa]).

No atual cenário da sociedade israelense, as cerimônias oficiais coletivas constroem uma relação direta entre o luto individual e o luto nacional, além de institucionalizarem essa dinâmica. Sendo assim, os pais enlutados acabam tendo que aprender a viver dessa forma e a reorganizar suas vidas a partir da perda, pois tudo na sociedade os remete a seus filhos 
mortos. Em Israel, o enlutamento parece, então, superar o caráter temporal e não se restringir ao âmbito familiar, tornando-se parte da realidade de todos os cidadãos.

De acordo com Rubin, Malkinson e Witztun (1999), para entender a relação entre luto pessoal e luto coletivo na sociedade israelense, é importante examinar as mudanças ocorridas na percepção das "unidades de referência" dominantes. A mudança mais notável é a que ocorreu dentro de Israel a partir de uma sociedade coletivista - como tradicionalmente exemplificada pelos kibutzim -, fundada com base em ideais e valores estatistas e socialistas, que preconizavam o bem comum como algo soberano. A partir da década de 1990, observase, cada vez mais, uma forte inclinação ao individualismo. Isso significa que, atualmente, existe inegável propensão à valorização do caráter pessoal de determinados acontecimentos e fenômenos, em detrimento do seu caráter coletivo. Entretanto, deve-se destacar que, apesar das transformações que vêm ocorrendo ao longo dos últimos 30 anos, quando a questão é o enlutamento, ainda há um forte apelo social, e o aspceto coletivista se sobrepõe.

\section{O luto como construção social: a manutenção da dor e do trauma}

As tentativas de preservar a memória dos que morreram na luta para estabelecer o Estado de Israel e em guerras subsequentes representam uma forma muito significativa como a sociedade lida com um trauma decorrente da perda. A manutenção do luto acaba por ter muitas funções sociais, como, por exemplo, não deixar que os mortos pela pátria sejam esquecidos, atribuir um sentido coletivo à sua morte, ressignificar a vida dos que permanecem vivos, além de reforçar a coesão social e nacional etc.

Eventos de rememoração foram instituídos nas esferas pessoais, sociais e nacionais. $\mathrm{O}$ Dia da Lembrança, no qual cerimônias são realizadas em cemitérios militares por todo o país, coincide com o período de dez dias entre o Dia da Memória do Holocausto e o Dia da Independência. Uma lei especial aprovada para tal finalidade inclui um adendo detalhado abordando variados atos memorialísticos de nível individual.

Ao longo dos anos, com o crescente número de soldados tombados nas guerras, pode-se afirmar que uma "cultura do enlutamento" surgiu, refletindo a importância que tem a morte de seus jovens para a sociedade israelense. $\mathrm{O}$ sentido de heroísmo associado à morte desses militares confere significado existencial, chegando ao nível nacional. Essas formas de 
perpetuação da memória desempenham um papel muito importante tanto no processo de luto individual como no processo de luto nacional (WITZTUM; MALKINSON, 1993).

A expressão coletiva relacionada ao sacrifício dos soldados é resumida na declaração "por sua morte que nos legou a vida". Isso não só descreve o significado social e cultural da morte dos jovens, como também molda as relações entre o indivíduo enlutado e a sociedade. Dessa forma, constitui-se um significativo reconhecimento de valorização do trauma.

Nehemiah Shtrasler, colunista do jornal HaAretz, por ocasião das comemorações do Dia da Lembrança e do Dia da Independência em Israel, escreveu:

\begin{abstract}
A vida não é mais o valor principal. Sacrifício e morte são os novos valores. Israel tem os locais mais memoráveis do mundo, um monumento para cada 17 mortos, em média, enquanto na Europa há um monumento para cada 10.000 tombados. Temos santificado a morte por mostrar respeito apenas àqueles que estão mortos. A triste história de sua perda prematura é contada principalmente com resignação, como se tal destino não pudesse ser alterado. [...]

Morte neste país tem níveis e classes. Cair morto como qualquer um na rua não é nada. Se você é um bombeiro que arrisca sua vida, e morre fazendo seu dever, também não é suficiente. Somente se você tombou em guerras de Israel - só assim - a sua morte é considerada alguma coisa. Só então você pode ser inscrito no rol dos mais honrados. [tradução nossa]
\end{abstract}

Por esse motivo, Stroebe e Gergen (1992) ratificam a ideia de que o luto e seus resultados deveriam ser examinados em um contexto sociocultural. Modernas teorias que analisam as reações à perda indicam que deveria haver uma quebra do vínculo com o morto. Em contraste, o ethos romântico enfatiza fortemente a manutenção dos vínculos, sugerindo que uma possível ruptura acabaria até mesmo com a identidade do enlutado e com o sentido de sua vida. Os autores ainda afirmam que algumas culturas têm normas e hábitos de supressão de memórias e mantêm sob controle os sentimentos dos cidadãos, ao passo que outras possuem normas sociais totalmente opostas, como é o caso da sociedade israelense.

Tais aspectos sociais da dinâmica do enlutamento seguem permeando não só o dia a dia de Israel através de ritos memorialísticos oficiais, mas também, mesmo fora desses momentos, o imaginário coletivo. Além disso, como não poderia deixar de ser, das diversas manifestações artísticas que assumem a abordagem desse tema, a literatura talvez seja a que mais sintomaticamente a absorve. O presente trabalho propõe, nas próximas páginas, uma breve análise das principais obras do escritor contemporâneo David Grossman que lidam com

\footnotetext{
${ }^{1}$ Disponível em: <http://www.haaretz.com/opinion/in-israel-you-re-not-somebody-until-you-re-dead-1.361421> Acesso em: 28 jul. 2016.
} 
a questão, o qual é, ele mesmo, não só um cidadão israelense, um formador de opinião e um adepto da esquerda do país, como também pai enlutado.

\section{David Grossman: escritor, ativista político e pai enlutado}

Nascido em 25 de janeiro de 1954, em Jerusalém, Israel, David Grossman tornou-se um dos principais autores da literatura contemporânea de seu país, juntamente com A. B. Yehoshua e Amós Oz. Os três escritores são considerados a "consciência viva de Israel", atualmente engajados também no cenário político da sociedade, tornando-se, muitas vezes, símbolos de oposição a determinados líderes de governo.

David Grossman nasceu somente seis anos após a criação do moderno Estado de Israel, em um cenário de fortes contradições. A mais contundente de todas era a convivência entre a memória da dor de um povo perseguido - e quase dizimado - durante a Segunda Guerra Mundial e a euforia da formação de um estado judaico israelense, legítimo e reconhecido pela comunidade internacional.

A mãe de David Grossman, Michaella Grossman, nasceu durante o período do Mandato Britânico na Palestina. Seu pai, Ytzhak Grossman, emigrou da Polônia, aos nove anos, com sua mãe, que, a essa altura, já era viúva. Foi com seu pai, bibliotecário, que David Grossman construiu, desde muito cedo, grande interesse pela leitura. No futuro, seria escritor e, como outros autores israelenses, viveria da sua própria literatura, traduzida no mundo todo para mais de 30 línguas.

Assim como todo jovem, David Grossman serviu à força nacional do seu país. Trabalhou no serviço de inteligência do Exército Israelense durante anos, até ingressar na Universidade Hebraica de Jerusalém, onde se formou em Filosofia e Teatro. Casou-se com Michal Grossman e tornou-se pai de três filhos: Yonatan, Ruth e Uri Grossman. Hoje, mora em Mivasseret Zion, subúrbio de Jerusalém.

A. B. Yehoshua, Amós $\mathrm{Oz}$ e David Grossman deram uma nova identidade à literatura israelense contemporânea e influenciaram significativamente o cenário político do Estado. Os três autores, inicialmente, chegaram a apoiar Israel na escalada militar contra o Hezbollah, na guerra contra o Líbano de 2006. Eles acreditaram que houve exagero na retaliação empreendida contra os árabes e lideraram um pedido de cessar-fogo, em 10 de agosto do mesmo ano. 
Vinte dias após os três autores chamarem a atenção, em uma conferência com a imprensa, para a necessidade de interrupção do conflito, um dos filhos de David Grossman sargento do exército de Israel - faleceu durante uma missão no sul do Líbano. Uri Grossman foi atingido por um míssil antitanque pouco tempo antes de o governo de Israel suspender as operações contra os árabes palestinos. Grossman não mudou de opinião em relação à política de seu país, mesmo com a morte de seu filho Uri. Pelo contrário, cada vez mais, dedica-se à luta pelo reconhecimento da necessidade de paz por parte dos israelenses. O escritor tornou-se símbolo de oposição ao governo de Ehud Olmert, o então primeiro-ministro de Israel, principalmente dois meses depois da morte de seu filho, quando falou a uma multidão de mais de 100.000 israelenses, que se reuniram para recordar a data de assassinato de Ytzhak Rabim, em 1995. Nesse dia, David Grossman denunciou a liderança do governo do Estado e convocou o povo a refletir, dizendo que, somente se estendessem a mão ao povo palestino, poderia haver esperança de paz entre Israel e outros países do Oriente Médio.

Quando perguntado sobre suas obras e sobre os ecos de sua própria vida nelas, Grossman sempre fala sobre a necessidade que tem de levar para sua literatura aquilo que o perturba. Ele, constantemente, faz questão de afirmar que a literatura traz à tona coisas que, em geral, negamos com naturalidade e que não queremos confrontar. No entanto, ao trazê-las à superfície, elas se tornam parte de nossa vida, e é então que podemos refletir sobre elas. Ele acredita que não se pode e não se deve fugir daquilo com que se é difícil lidar, pois fugir do que nos confronta é fugir de nós mesmos (GROSSMAN, 2011).

No que diz respeito aos seus personagens, Grossman procura retratá-los em toda a sua complexidade, colocando em questão suas crises e contradições. Ainda que a temática de demandas coletivas seja bastante emblemática em suas obras (como, por exemplo, a memória da Shoá, o conflito israelo-palestino, o enlutamento social de Israel etc.), é através de problemas de personagens individualizados que o escritor as aborda. Dessa forma, evidencia-se a preocupação de Grossman em fazer aspectos do coletivo ganharem voz através do sujeito, para que, à medida que são particularizados, se façam mais intensos e pessoais.

\section{A mulher foge: a anunciação da morte}


No ano de 2006, David Grossman estava terminando a redação de seu mais importante livro sobre o conflito israelo-palestino, considerado pela crítica literária israelense o mais antibélico do país: Ishá borahat mibessorá .

No idioma original, o título do romance contém a palavra bessorá, que significa, em hebraico, "anunciação" e evoca a conotação de "profecia". O termo também é utilizado, em contexto religioso, essencialmente para designar a chegada do Messias. Desse modo, desde o título, pode-se observar o seguinte contraste: enquanto bessorá pode se referir à vinda do Messias, no romance de David Grossman, está prestes a anunciar uma partida.

O romance nos conta a história de Orah, uma mulher de quase 50 anos, que teme receber a notícia da morte de seu filho, Ofer, alistado para uma última missão no Exército de Israel. Em virtude desse medo, a mãe toma uma decisão: fugir em direção ao norte do país com Avram, seu amigo, antigo amor e, por acaso, pai do próprio Ofer.

Orah, divorciada de Ilan, é mãe de dois jovens que serviram ao exército do país por três anos. O mais velho já deu baixa no alistamento, mas o mais novo ainda está trabalhando, pois, mesmo oficialmente dispensado, procurou estender seu período de serviço em mais um mês, a fim de participar de uma última incursão. A mulher não aguenta mais permanecer em sua casa, já que, todos os dias, tem que lidar com a possibilidade de receber, a qualquer momento, a tão temida notícia sobre a morte de seu filho. Orah foge, mas é na fuga - em princípio, evidência de fraqueza - que revela sua força.

A figura de Ofer é bastante interessante, visto agregar em si diversas características emblemáticas do jovem israelense da atualidade, sendo muito apaixonado por seu país e estando disposto a correr todo tipo de risco pelo bem da nação. De acordo com Krausz (2010),

[...] Ofer, ao que parece, é um herdeiro daquele ethos guerreiro dos antigos gregos que, de maneira implícita, está presente na figura mítica do soldado israelense, criada pela ideologia sionista nos primórdios do Estado, e profundamente inspirada pelo romantismo europeu. Trata-se de um herói guerreiro que, ao mesmo tempo, é alguém que jamais transpõe os limites de uma ética profundamente judaica. Esta imagem do 'bom soldado' é uma das imagens centrais do imaginário israelense, sobretudo à época que antecede a criação do Estado, e é um dos modelos identitários das ondas migratórias em direção a Israel nas primeiras décadas do século 20.

Esse modelo romântico, porém, em nada corresponde à realidade da guerra retratada por Grossman, onde a sordidez e a violência imperam nas relações dentro da hierarquia militar, onde a desumanidade perpassa todos os aspectos do relacionamento entre

\footnotetext{
${ }^{2}$ Literalmente, o título do romance pode ser traduzido como "A mulher foge da notícia". No Brasil, foi publicado como $A$ mulher foge.
} 
comandantes e seus subalternos, e onde os mais poderosos são sempre os mais brutais e inescrupulosos. (KRAUSZ, 2010)

O texto de Grossman registra o contraste entre o ideal de guerra e de soldado corajoso e a realidade angustiante do ambiente no qual os jovens militares estão inseridos. Indo de encontro ao imaginário de heroísmo israelense, Grossman fala sobre um mundo dilacerado pela guerra, onde morrer pelo seu país não é glorioso e, menos ainda, uma causa nobre. $\mathrm{O}$ autor traz à tona o alto preço que se paga por se querer estar constantemente em guerra, com seus supostos heróis morrendo em nome de causas patriotas que se julgam justas, mas, na realidade, dando suas vidas por motivos ilusórios, pelos quais se perde muito mais (GROSSMAN, 2011).

É por causa da decisão de Ofer, de se oferecer para lutar uma última vez por Israel, que Orah decide partir com Avram. Durante sua viagem, a mulher aproveita para apresentar, através de histórias, seu filho ao pai, que não o conhece bem, pois o jovem fora criado por seu ex-marido. A mãe conta a vida de Ofer desde o dia do seu nascimento até o momento em que ele se alistou no exército. Essa narrativa vai inteirando Avram da trajetória do rapaz e, ao mesmo tempo, consolidando-se como estratégia da qual se pode lançar mão para proteger Ofer.

De certa forma, Orah acredita que, quando conta "com palavras" como era a vida de ambos, ela faz não só com que o pai se aproxime do filho, como também insufla um pouco de vida ao próprio Ofer. Suas histórias dão calor e vitalidade ao rapaz que está longe. Ela acredita poder afastá-lo da morte e trazê-lo para perto de si, onde será protegido de todo mal. Assim, narrar apenas "com palavras" a vida de seu filho é também, em certa medida, fazer algo para tenta reverter o que, aparentemente, já está anunciado.

Orah, que praticamente obriga Avram a sair com ela em viagem, o faz porque tem forte intuição de que Ofer será ferido ou morto durante o conflito. Ela decide fugir das más notícias que poderão chegar, já que, para ela, são necessárias duas pessoas para que uma má notícia se concretize: uma pessoa que a dê e outra que a receba. Por isso, ela decide que não vai ser a pessoa que recebe.

Além medo da notícia que está por vir, a mulher se aflige por ela mesma ter levado o Ofer à última operação militar. Foi ela quem acompanhou o filho ao alistamento. Sobre esse dilema de Orah, Nancy Rozenchan explica: 
Orah [...] é mãe de dois filhos, que combinou viajar com o mais novo deles pela Galileia quando ele desse baixa no exército. Ao invés, ela o conduz a um posto do exército estabelecido devido aos atentados, de onde ele sairá para uma última missão. O grande medo de Orah é receber uma má notícia sobre o filho; soma-se a dor de ter sido ela própria aquela que o conduziu para a missão; ela não se conforma de ter obedecido a tudo, a eles, àqueles que o enviaram para lá. $\mathrm{Na}$ prática, é ela que leva o filho para a batalha, a "akedá", a condução ao sacrifício ao estilo do Isaque Bíblico. (ROZENCHAN, 2011, p. 37)

Aqui, Rozenchan chama a atenção para o sacrifício de entregar o próprio filho a quem vai lhe tirar a vida. É a tristeza de que o filho pode estar caminhando em direção à morte, levado por ela própria, que vai consumindo os dias de Orah. A angústia pela possibilidade de Ofer não retornar faz com que a mulher se recuse a ficar em casa para ter a confirmação do falecimento. Paralelamente, está o fato de o próprio filho ter pedido à sua mãe, antes de partir em sua última incursão, que, se lhe acontecesse qualquer coisa durante a guerra, ela deveria ir embora do país. Em sua longa viagem por Israel, Orah tem a sensação de que, se não voltar para casa, ajudará o jovem a sobreviver aos conflitos. Apesar de tentar dar fôlego à sua esperança, Orah se dá conta de que está em uma condição irreversível de exílio, pois ser israelense é viver em permanente estado de guerra. Salta aos olhos, então, que os protagonistas de Grossman lutam para viver sua humanidade em um contexto inequivocamente desumano.

A propósito da sua motivação para a viagem - que tem data de partida, mas não de chegada; que tem local de saída, mas não rumo certo -, destacamos um dos episódios em que Orah tem um pesadelo sobre a chegada de três oficiais do Exército de Israel, que vão até sua casa para lhe dar a tão temida notícia:

E Orah, apesar de tudo, aparentemente conseguiu adormecer, pois ao amanhecer foi despertada por três homens com fardas do exército parados na pequena clareira diante de sua porta. Eles se espremeram um contra o outro para que o oficial mais velho se adiantasse para bater na porta, e o médico apalpou sua maleta em busca de uma injeção tranquilizante e a oficial mais jovem estendeu os braços preparando-se para segurá-la caso ela desmaiasse.

Orah viu os três se aprumando e se incentivando mutuamente. O mais velho ergueu a mão e hesitou por um instante, e ela, hipnotizada, olhou para sua mão fechada, ocorrendo-lhe que esse momento se prolongaria pela vida inteira. Então, ele bate na porta, dá três batidas fortes, e fica olhando para a ponta de suas botas, e enquanto esperava a porta se abrir, fica ensaiando silenciosamente o texto da notícia, a saber: em tal-e-tal hora, em tale-tal lugar, o seu filho Ofer, que estava em missão numa operação...

[...] Finalmente Orah conseguiu mover os pés procurando se colocar sentada dentro do sleeping bag. Estava banhada em suor frio, os olhos fechados, as mãos rígidas, e tinha a impressão de que não conseguiria mais movê-las. O oficial mais velho deu outras três 
batidas e, talvez por não desejar fazê-lo, acabou batendo forte demais; momentaneamente parece querer derrubar a porta e entrar à força com a notícia, mas a porta está fechada e ninguém abre para querer receber a notícia que ele tem para dar, e ele olha desapontado para o documento que tem em mãos, que diz explicitamente que em tal-e-tal hora, em tale-tal lugar, o seu filho Ofer, que estava em missão numa operação...

[...] Com um grito abafado, Orah irrompe do maldito sleeping e sai da barraca em corrida desabalada, parando do lado de fora zonza e com expressão aterrorizada. Só depois de alguns instantes, percebe Avram sentado no chão não muito longe dela, encostado numa árvore, olhando para ela. (GROSSMAN, 2011, p. 158, 160 [grifos da autora])

O episódio trata do momento em que Orah projeta, no sonho, o que teme que aconteça na realidade. E, mesmo no sonho, ela não está em casa para receber a notícia da morte de Ofer, o que faz com que haja, então, uma possibilidade de salvar seu filho. No pesadelo, Orah vê os oficiais encarregados de avisá-la e, devido ao choque que a informação lhe causa, ainda enxerga um médico que tateia suas coisas, à procura de uma injeção tranquilizante. Isso vai conferindo peso de angústia ao seu sono, e ela se vê em um momento de aflição que parece não ter fim. Fisicamente, Orah parece estar em um estágio entre o sono e o despertar, até que um dos oficiais, que ensaia como noticiar-lhe fato, diga seu texto pronto, já conhecido em casos de perda de membros da família em combate militar.

Ao longo da narrativa, é possível observar que o texto pronto da notícia se repete mais algumas vezes na imaginação e nos sonhos da mãe, em razão da agonia que ela experimenta. É como se ela tivesse certa convicção de que era questão de tempo que ouvisse dos oficiais a má notícia. No sonho, o texto está prestes a sair da boca de um dos militares, rompendo o silêncio da esperança de vida, e se dirigir aos ouvidos e ao coração da mãe. Entretanto, como ela não está em casa para ouvir a notícia, a morte de Ofer também fica em suspensão. É por isso que o texto pode estar pronto e pode ser por ela esperado, mas, se ela não estiver disposta ou disponível a recebê-lo, como realmente não está, ele não ganhará forma e, consequentemente, não será sua realidade de dor.

Assim como Orah, Grossman também desejou, de alguma maneira, proteger seu filho. Orah saiu de casa para não receber a notícia, enquanto o autor escreveu um romance com a pretensão de salvaguardar Uri. As palavras a seguir estão registradas na contracapa de $A$ mulher foge e nos permitem contato com a experiência de ter escrito seu texto em paralelo com a morte de seu filho:

Comecei a escrever este livro em maio de 2003, meio ano antes do término do serviço militar do meu filho mais velho Yonatan, e meio ano antes do alistamento de seu irmão mais novo, Uri. Ambos serviram nos blindados. 
Uri conhecia muito bem o enredo e os personagens do livro. Toda vez que conversávamos por telefone, e especialmente quando vinha para casa em sua folga, perguntava o que havia de novo no livro e na vida de seus protagonistas (O que você armou para eles esta semana? Era sua pergunta constante.). A maior parte do seu tempo de serviço ele passou nos territórios ocupados, em patrulhas, vigília, emboscadas e barreiras, e ocasionalmente compartilhava comigo suas experiências. $\mathrm{Na}$ época eu tinha a sensação - ou melhor, o desejo - de que o livro que eu escrevia o protegeria.

Em 12 de agosto de 2006, nas últimas horas da segunda guerra do Líbano, Uri foi morto no sul deste país. Seu tanque foi atingido por um míssil durante o processo de resgate de outro tanque atingido. Junto com Uri morreram todos os membros da equipe de seu tanque $[\ldots]$.

Depois do período de shivah, voltei ao livro. A maior parte dele já estava escrita. O que mudou, acima de tudo, foi o eco da realidade na qual foi escrito o último esboço. (GROSSMAN, 2011 [grifos do autor])

A realidade inominável do autor reverberou em seu texto no momento final de sua escrita. Agora, não se tratava de um personagem seu que havia perdido seu filho durante a guerra, mas se tratava dele próprio, que se convertia em pai enlutado.

Apesar de trabalhar o tema principal da perda através de uma fuga, o livro não privilegia o escapismo como forma de lidar com os problemas, embora essa atitude também seja comum em Israel. Talvez seja justamente por isso que Grossman tenha decidido abordar a fuga, já que ela constitui uma reação humana natural e que serve como medida protetiva. Uma vez que é tão difícil conviver com uma realidade violenta, intrusiva e ameaçadora, o escape acaba por ser uma forma de simplesmente sobreviver à ameaça. No entanto, no caso da protagonista do texto, escapar não é sinônimo de fraqueza. Ao contrário, escapar é mover-se, é fazer alguma coisa para não se deixar envolver pelo caos prestes a se instaurar. Fugir pode mexer com toda a engrenagem do anúncio da morte do filho e reverter a situação. Em suma, a atitude de escapar parece ser um recurso de que Orah dispõe para mudar as coisas.

É importante também pensar sobre a opção de Grossman por uma personagem feminina para estar na linha de frente do texto. Talvez - embora haja certa generalização nisso -, a mulher tenha algo de mais subversivo em si mesma e em suas atitudes. Isso explica por que ficou bastante perturbada com o fato de ter entregado seu filho ao governo. Como é possível que ela seja, de certa forma, mais leal a ele do que a si própria, assim como ao exército, ao país, à guerra, a esse sistema tão violento que tira os filhos das famílias? Como ela pode não ser leal ao seu principal papel de mãe de Ofer? Por isso, essa entrega não é feita em paz, como a entrega bíblica de Isaque por Abraão. Nesses termos, pode-se observar o quanto as posturas de Abraão e Orah são díspares. A entrega da mulher, em quem todos esses fatores resultam na decisão de fugir, é uma entrega inconformada, incômoda e cheia de angústia. 
Muitas lacunas ficam por ser preenchidas ao término do romance. Textos lacunares são uma marca muito forte de David Grossman, que acredita que o silêncio também tem muito a dizer - não raramente, mais do que qualquer palavra. Dessa forma, a revelação, em sua obra, se constrói pelo não dito, ou seja, pelo que fica em suspenso. O silêncio, enfim, em seus textos, sempre se mostra capaz de comunicar.

Assim como Orah, Grossman entregou seu filho ao serviço nacional de seu país, perdendo-o durante uma incursão militar. E, assim como a mulher acreditava que, se não estivesse em casa para receber a tão temida notícia, conseguiria mudar as coisas, Grossman escreveu esse romance na esperança de não deixar que nada de mal acontecesse a seu filho. É como se tanto a personagem quanto Grossman se recusassem a aceitar, com passividade, que a morte tragasse algo que lhes era muito seu, que era parte de si.

\section{Fora do tempo: o luto concretizado}

Cinco anos após a morte de seu filho, Grossman lança um livro chamado Nofel michutz lazman $^{3}$, no qual prosa e poesia se sobrepõem. Essa arriscada forma de construir o texto resultou em um equilíbrio de gêneros textuais distintos, para tratar da temática da morte. Sem a pretensão de dar conta dela, mas assumindo a necessidade de sobre ela refletir, a combinação prosaico-poética confere momentos de fluidez textual associados à hesitação, à impossibilidade de expressar, perfazendo um caminho onde voz e silêncio se intercalam.

O romance em versos de David Grossman nos faz conhecer a história de um Homem que, depois de um período de cinco anos de total emudecimento, recupera a fala e anuncia à Mulher, sua esposa, que está de partida para um lugar onde espera encontrar seu filho já morto. Esse local é chamado pelos personagens de "lá", o que nos mostra uma significativa relutância por parte deles em nomeá-lo. O "lá", assim denominado por ser tão denotador de sofrimento e terror e que existe em paralelo com o lugar de vida, precisa ser distanciado e evitado, sem que se possa falar sobre ele com naturalidade. A Mulher resiste à ideia do Homem e tenta convencê-lo de que não deve ir. No entanto, seu marido ignora a contestação e parte mesmo assim, andando em intermináveis círculos. Sua partida instaura uma agitação na cidade onde moram, na qual todos os pais estão igualmente enlutados.

\footnotetext{
${ }^{3}$ Literalmente, "Caindo fora do tempo". Publicado, no Brasil, como Fora do tempo.
} 
O texto tem ambientação de drama medieval, principalmente devido à presença de alguns personagens característicos, como o Duque e o Anotador dos Anais da Cidade. Este, a serviço daquele, registra a consternação e a melancolia transmitidas nos testemunhos dos pais que perderam seus filhos. Além disso, o Anotador dos Anais da cidade trava constante embate com outro ser, que tem a aparência de um centauro - um homem metade escritor, metade escrivaninha. O Anotador enfurece cada vez mais esse ser, por lhe pedir detalhes precisos de sua angústia de luto, fazendo a relação se tornar bastante tensa entre eles. Tem-se, aqui, portanto, duas figuras muito emblemáticas, que tentam expressar antíteses de um mesmo ponto-chave: o Centauro-escritor, que, estando de luto, se vê incapaz e impotente diante de sua escrita e do propósito dela, ou seja, ele se acha em bloqueio criativo; e o Anotador, que, também enlutado, enche seus relatórios de descrição, a partir da observação do trauma dos outros, na ânsia por sufocar seu próprio trauma. Esses personagens oscilam entre manifestações recíprocas de fúria e consolo mútuo, uma vez que, mesmo tão diferentes, compartilham, simultaneamente, da mesma experiência de aflição.

Somam-se a esses personagens de maior relevo outros muitos que integram essa cidade tão cheia de pais que choram, com pesar incessante, a morte de seus filhos. À sua maneira, cada um vai relatando sua dor, recordando cenas do passado recente e distante ainda na companhia de seus filhos. Esse contexto vai se delineando à medida que as famílias vão permanecendo em um ciclo sem fim de lamento, melancolia e saudade. Ao longo do texto, o estado de desolação que se abate sobre os que vivem vai se encarregando de construir a agonia dos pais, por estarem irremediavelmente "órfãos". Essa orfandade ao inverso se mostra reveladora de tentativas e inabilidades do ser humano que se relaciona com um tipo de perda irreparável. E, ainda, sem nomear essa sociedade como "israelense", estamos justamente diante de seu cenário. David Grossman aborda o contexto cotidiano do país e traz os sentimentos individuais e coletivos característicos de sua dura realidade, sem, no entanto, inscrever a obra no contexto contemporâneo de Israel. Descortina-se, diante de nossos olhos, então, através da ficção, a mesma dinâmica de enlutamento que começou a ensaiar seus primeiros momentos no período de formação do Estado de Israel e que vigora até os dias de hoje.

Em seguida, é possível observar como Grossman, através da poesia entrelaçada à ficção, trabalha a questão da ausência de um dos vários filhos que a cidade perdeu como permanente presença na vida dos pais: 
ANOTADOR DOS ANAIS DA CIDADE: E quando ela diz essas coisas, ele para de andar em volta dela. Ela olha para ele com olhos opacos. Com os braços caídos, perdido, ele fica diante dela, como se nesse momento o tivesse atingido uma flecha disparada há muito tempo.

\author{
MULHER: \\ Voltarei \\ um dia \\ a vê-lo como \\ você é, e não como \\ ele não é?
}

\title{
HOMEM:
}

Posso lembrar

de você sem

ele não estar - o teu sorriso, inocente

e otimista - de mim também,

sem ele não estar, eu posso

lembrar. Mas dele,

que estranho:

dele, sem a ausência dele, não posso

mais lembrar. E quanto mais

se alonga o tempo,

mais parece que

quando ele ainda estava

já se exumava dele

seu não estar -

\section{$[\ldots]$}

\section{MULHER:}

Naquela noite pensei,

agora vamos nos separar. Juntos não mais

poderemos estar. Quando eu lhe disser

sim,

você abraçará o não,

a ausência dele

você vai abraçar -

\section{HOMEM:}

Como chegarmos, pensei

naquela noite,

como achegar-nos um ao outro?

Quando eu a beijar

cortarão minha língua

os cacos de vidro

do nome dele

em sua boca -

MULHER:

Como olhar em meus olhos se ele está lá 
primal como um feto

no negror

da pupila?

Todo olhar, todo

toque serão

cutiladas. Como amar,

pensei naquela noite,

como amaremos

se a ele

num grande amor

concebemos? (GROSSMAN, 2012, p. 22-24)

O olhar do Anotador dos Anais da Cidade, sob a forma da prosa, em seu papel de observador dos outros personagens que têm que levar suas vidas a partir da nova condição de ausência do filho, é também uma espécie de vivência do processo do luto, carregado de consternação.

Ele transmite ao Duque não somente as atitudes do Homem e da Mulher tal qual elas são, como também faz comparações a partir de suas próprias impressões. Seu relatório não é meramente descritivo e imparcial, mas é também seu sentimento diante da dor dos outros, que acaba sendo igualmente sua própria dor. Então, ele é um pouco de cada um desses homens e mulheres que observa, e cada um dos observados é um pouco dele também. Logo, quando ele vê o Homem e pensa que ele age como se acabasse de ser flechado por uma seta que fora lançada havia muito tempo, é porque ele mesmo se sente assim também.

Em seguida, o trecho aborda o que vai ser tematizado ao longo de toda a obra: a morte como presença constante na vida dos personagens. A ausência dos filhos, que está sempre pesando sobre suas almas, acaba sendo a única coisa que direciona seus pensamentos, suas decisões e reflexões sobre a vida. Seu presente sufocante faz com que as esperanças sejam perdidas, nada mais voltando ao que era. O tempo todo, os personagens pensam sobre a morte e sobre tudo o que ela lhes arrancou, de uma hora para a outra, trazendo uma espécie de sensação infernal de vazio.

Lidar com a perda é tão irremediavelmente necessário, visto ser a condição real de suas vidas, que eles já nem conseguem se ver mais, no presente, sem que a morte faça parte deles próprios. E, pior, se eles não tiverem a ausência de seu filho presente em suas vidas, admitem não conseguir nem mesmo senti-lo mais, pois ele, agora, se manifesta apenas sob a forma da ausência. É como se a ausência fosse o único meio para que a presença dele seja, de alguma forma, real. Apesar da ausência física, o filho sempre vai ser parte deles, ainda que por meio da sua não vida ou do seu não lugar na vida. 
Salta aos olhos não somente a relação desses pais com a "ausência-presente" do filho, mas também a relação deles entre si mesmos, enquanto casal. Eles cogitam assumir a total incapacidade de serem parte um do outro, se não se tem mais entre eles a terceira parte que os compõem. Se os três formavam um só e, agora, uma parte dessa unidade não existe mais, não há unidade. Eles pensam em como seria difícil cogitar um amor real a dois, se a mais real prova de seu sentimento um pelo outro não existe mais enquanto presença física, mas só como ausência. E, se está ausente o fruto da relação, o amor entre eles se esvai. Dessa forma, pensam-se não somente as relações que têm que lidar com a perda do outro, que é, na verdade, parte de si e que não está mais ali (o filho), mas também as relações com o outro que se torna não parte, estando ainda ali (o cônjuge).

David Grossman acabou a redação desse texto e o publicou justamente cinco anos depois da morte de Uri Grossman, seu filho. Cinco anos foi seu período de emudecimento, assim como o período de emudecimento do Homem, seu personagem, que anda em círculos e deseja ir para "lá". Imediatamente após a publicação dessa obra, em Israel, o autor preferiu não conceder entrevistas, possivelmente porque o texto se trata de uma investigação íntima e pessoal de sua experiência com a perda de Uri - experiência tão próxima dos limites do inexprimível que o escritor se vale de vários tipos de recurso, que variam desde a mescla de gêneros textuais (poético e narrativo) à fantasia do ser metade homem, metade escrivaninha, subvertendo as fronteiras da expressão puramente realista, na ânsia por dar voz ao luto e ao caos advindo dele.

Grossman opta pela poesia por ser ela uma espécie de linguagem mais próxima da dor. A poesia se aproxima mais do silêncio, na visão do próprio escritor, e aborda a questão da morte em sua contenção, em seu sentimento de voltar-se a si mesmo, em sua condição de falar através do não dizer. Já a prosa intercalada, parece ser trabalhada para conferir ao texto poder de narrativa, com seus elementos característicos, como personagens, enredo, tempo e clímax.

Enfim, Grossman parece ter encontrado um maravilhoso meio-termo entre o conter e o soltar um grito.

Esses dois recentes textos de David Grossman - A mulher foge (2011) e Fora do tempo (2012) - tocam as questões mais sensíveis e complexas não só de sua vida pessoal, como também da sociedade israelense como um todo. No primeiro, encontra-se uma profecia do caos, e, no segundo, constrói-se, de modo demasiado duro, a concretização desse caos. Em um, prevê-se a morte; no outro, ela está consumada. Ambas as obras trazem à tona as 
angústias dos pais israelenses, bem como sua tão possível e, por vezes, inescapável realidade de perda. Sentimentos individuais e coletivos relacionados ao luto são investigados pormenorizadamente. O que está registrado nos textos do escritor israelense e pai enlutado diz respeito à sua condição inominável de tristeza particular, assim como à agonia que todo cidadão de Israel carrega por estar submerso em um contexto sem perspectivas de transformação, em que guerra é freqüente e a relação com a morte, impossível de ser ignorada.

\section{Considerações Finais}

A perda e o luto, na sociedade israelense, podem ser considerados um exemplo de interação contínua entre os indivíduos e seu contexto sociocultural. Os elementos universais e particulares relativos à dor e ao luto encontram terreno fértil, sobretudo, com o suporte de uma dinâmica que é, cada vez mais, reforçada ao longo do tempo. No caso de Israel, essa dinâmica é reproduzida por diferentes grupos sociais e institucionalizada oficialmente pela liderança do Estado. A sociedade israelense, embora esteja sob um recente processo de passagem de uma visão predominantemente estatista e orientada ao bem comum para uma perspectiva essencialmente individualista, ainda reflete, muito claramente, sua pré-disposição para a manutenção dos vínculos entre os cidadãos enlutados, os jovens tombados em guerra e a sociedade como um todo.

Os eventos que visam à memorialização dos soldados mortos acabam por enfatizar o enlutamento individual e, ao mesmo tempo, o enlutamento coletivo, fazendo com que o sentimento de consternação ganhe proporções nacionais e seja uma das principais e incontestáveis marcas da sociedade de Israel. Isso significa que, enquanto outras culturas se preocupam com a tentativa de rarear os sofrimentos pessoais e sociais, com o objetivo de amenizar as dificuldades e seguir adiante, a israelense parece fazer questão de permanecer conectada com eles incessantemente.

Talvez, um rumo diferente para esse cenário esteja lentamente se apresentando, por meio da consolidação de uma maior consciência da natureza multicultural e multiétnica que vem emergindo nos últimos anos no país. Devido à crescente instalação de judeus não israelenses em Israel e mesmo de outros grupos que buscam respostas, sobretudo, de ordem econômica, um novo contexto parece que começa a se projetar. As mudanças sociais decorrentes dessa transformação proporão uma alternativa à sociedade, que se apegou fortemente à dinâmica de perpetuação da tristeza e do luto. 
Em suma, quando Israel olha para trás, reconhece que seus quase 70 anos de existência como Estado moderno foram significativamente marcados por todo tipo de realizações que, há bem pouco tempo, pareciam absolutamente intangíveis. Entretanto, o preço humano que foi pago para que se chegasse a essa condição foi alto e continua ressoando na sociedade até os dias de hoje. Na visão do escritor David Grossman, os israelenses precisam ter a convicção de que há uma opção e de que, não necessariamente, a única alternativa é fazer parte de uma guerra. Pelo contrário, pode-se preferir a vida à morte; pode-se escolher fazer concessões em troca de paz e saber que isso realmente vale a pena. 


\section{Bibliografia}

FREUD, S. Luto e melancolia (1917 [1915]). In: - A história do movimento psicanalítico: artigos sobre a metapsicologia e outros trabalhos (1914- 1916) - Vol. XIV. Rio de Janeiro: Imago, 1996, p. 245-263.

GROSSMAN, D. A mulher foge. São Paulo: Companhia das Letras, 2011. Fora do tempo. São Paulo: Companhia das Letras, 2012. . Roda Viva com David Grossman. [Publicado em 21/12/2011]. São Paulo: TV Cultura. 21 de dezembro de 2011. Disponível em: $<$ https://www.youtube.com/watch?v=XptSj-ATecM> Acesso em: 28 jul. 2016.

KRAUSZ, L. S. Guerra e paz, por David Grossman. Arquivo Maaravi, vol. 1, n. 6, março, 2010. Disponível em: <www3.ufmg.br/nej/maaravi/artigoluis-israel.html> Acesso em: 15 jul. 2016.

LEVY, A.; WITZTUM, E.; SOLOMON, Z. Lessons relearned-when denial becomes impossible: therapeutic response to combat stress reaction during the Yom Kippur War (1973) and the Lebanon War (1982). Israel Journal of Psychiatry, 33, p. 89-102, 1996.

MALKINSON, R.; BAR-TUR, L. The aging of grief in Israel: a perspective of bereaved parents. Death Studies, 23, 5, p. 413-431, 1999.

RICHES, G.; DAWSON, P. Communities of feelings. Mortality, 1, 2, p. 143-162, 1996.

ROZENCHAN, N. E nos lembraremos de todos. In: Ensaios sobre literatura israelense contemporânea. São Paulo: Humanitas, 2011.

RUBIN, S.; MALKINSON, R.; WITZTUN, E. The pervasive impact of war-releated loss and bereavement in Israel. International Journal of Group Tensions, vol. 28, n. 1/2, 1999.

STROEBE, M.; GERGEN, M.. Broken hearts or broken bonds: love and death in historical perspective. American psycologist, 47, 10, p. 1205-1212, 1992.

VOLKAN, V. (Ed.). Linking objects and linking phenomena. New York: International Universities Press, 1981.

WITZTUM, E.; MALKINSON, R. (1993). Bereavement and commemoration in Israel: the dual face of the national myth. In: MALKINSON, R.; RUBIN, S.; WITZTUM, E. (Ed.). Loss and bereavement in Jewish society in Israel. Israel: Canah/Ministry of Defense, 1993, p. 231-258. 